\title{
16-18. Yüzyılda Osmanlı Doğu Vilayetlerinde Safevi/Acem Hacılarıly İlgili Değerlendirmeler
}

\author{
Assessments on Safavid/Persian Pilgrims in Ottoman Eastern Provinces in 16-18th \\ Centuries
}

\author{
Dr. Öğr. Üyesi Esra DOĞAN TURAY ${ }^{1}$
}

\begin{abstract}
Özet
Safevî hacıları Osmanlı Devleti’nin kendilerine belirlediği Şam-Mekke güzergâhına ulaşmak için Erzurum-Urfa-Halep ya da Van-Urfa-Halep bağlantı yollarını kullanmışlardır. İki ülkenin rekabet alanından geçen bu yollar Safevî hacılarını bazen zor durumda bırakmış, tüm İslam coğrafyalarında dokunulmazlığı olan hacı olma durumu Acem hacılarını saldırılardan koruyamamışıtır. Hacıları korumak için Osmanlı devleti tarafından tayin edilen Acem Ağası çözümün bir parçası olmak yerine Kürdistan hâkimleri ve yerel halkla işbirliği yaparak sorunun bir parçası haline gelmiş, bu durum çoğu kez Osmanlı sultanları ile Safevî şahları arasında hoşnutsuzluğa sebep olmuştur. Buna rağmen Şii hacıların yolculukları hiçbir dönem kesintiye uğramamıştır. Acem hacılarının iki ülke siyasetinden kaynaklanan bu sıkıntıları Osmanlı resmi belgeleri, Safevî vakayinameleri ve döneme ait seyahatnamelerde açıkça görülmektedir.
\end{abstract}

Anahtar kelimeler: Safevî tarihi, hac tarihi, Acem hacıları, Anadolu hac güzergâhları, seyahatname

Makale Türü: Derleme

\begin{abstract}
Safavid pilgrims in order to reach Damascus-Mecca used Erzurum-Urfa-Aleppo or Van-UrfaAleppo route as connection paths which was determined by Ottoman Empire for them. Those roads sometimes made Safavid pilgrims left in a difficult situation because of a competitive field for two countries. The impunity of being a pilgrim in all Islamic territorries could not protect them from attacks. Persian Landlords was appointed by Ottoman Empire, in cooperation with Kurdistan Rulers and local community, became part of the problem instead of protecting pilgrims; this situation often caused discontents between Ottoman Sultans and Safavid Shahs. In spite of this, Shiite pilgrims never interrupted. The hardships that Persian pilgrims lived, on the grounds of the politics of the two countries, are clearly visible in Ottoman archives, chronicles and travelbooks of the Safavid.
\end{abstract}

Key Words: The history of Safavid, the history of the Pilgrimage, Anatolian Pilgrimage roads, travelbooks

Paper Type: Review

\footnotetext{
${ }^{1}$ Mardin Artuklu Üniversitesi, İslami İlimler Fakültesi, esra_dogan@hotmail.com, Orcid ID: https://orcid.org/00000001-7728-0037
} 


\section{Giriş}

Ortak sınırlara sahip Safevî (1501-1736) ve Osmanlı (1299-1922) müşterek tarih, 1rk ve dinî değerleri olan komşu devletlerdir. Bu iki Müslüman devlet siyasî, ticarî ve sosyokültürel açıdan sıkı ilişkilerde bulunmuş, Safevî ülkesinden Osmanlı coğrafyasına çeşitli sebeplerle yolculuklar yapılmıştır. Bunlar arasında Hicaz'a ve Irak'a Imamlar Ziyareti olarak bilinen Atabât-ı Aliyat'a yapılan seyahatler oldukça fazladır. Bu yoğun seyahatler Safevî Osmanlı siyasî ilişkilerinde Acem hacılar meselesini önemli kılmıştır. Devlet, Anadolu güzergâhından geçen Acem hacılara resmî güzergâhlar belirlemek ve bölge hâkimlerini hac mevsimi öncesinde uyarmak gibi birçok önlemle aşiretlerin ve halkın saldırılarından korumaya çalışmıştır. Yine de, Safevî döneminde Anadolu güzergâhından hacca giden Acem kervanları taciz edilip saldırıya uğramış, bu durum, Safevî Devleti'nin sonuna kadar önü alınamaz bir meseleye dönüşmüştür. Buna misilleme olarak Orta Asya, Kafkasya ve Hindistan'dan gelen Sünni hacılara geçit verilmemiş, bu hacılar Portekiz korsanlarına rağmen Hint Denizi'nden Kızıldeniz'e yolculuk yaparak Cidde'ye ulaşmaya çalışmıştır. Bu hacıların büyük bir kısmı da İstanbul'da halifeyi görmek ve Osmanlı resmi hac kervanına katılmak için Hazar-Karadeniz güzergâhını kullanarak Astrahan, Kazan ve Kırım üzerinden uzun ve tehlikeli yolculuklara girişmiş, Anadolu'dan geçen Acem hacıların yaşadığı benzer sıkıntılarla hacca gidip gelmişlerdir. Her iki coğrafyada yaşanan saldırı sebeplerini yalnızca mezhep çatışmalarında aramak bu hacıların aslında Anadolu, Kafkasya ve Irak'ta müşterek değerlere sahip İran ve Osmanlı devletleri arasındaki ekonomik ve bölgesel rekabete konu olduklarını görmemek anlamına gelecektir. Öte yandan hacıların yaşadığı sorunların temelinde siyasi faktörlerden ziyade geçtikleri güzergâhlardaki otorite boşluğu ve iktisadi etkenlerin sorgulanması gerekmektedir. (Küpeli, 2014. 49) Bu makale Safevî-Osmanlı siyasetinde kendileri için belirlenen resmi güzergâhlara ulaşacak Acem hacıların Doğu vilayetlerinden geçerken yaşadıkları olumsuz etken ve sonuçlara rağmen Osmanlı devletinin gösterdiği iyi niyete dikkat çeken bir çalışmadır.

\section{Safevîlerde Hac Olgusu ve Haccın Yasaklanması}

İranlıların Hicaz'la ilişkilerinin oldukça eski ve güçlü olduğu bilinen bir gerçektir. Haccı bir kenara bırakırsak Emeviler döneminden itibaren İranlıların Hicaz'la derin bağlar kurduğu, Horasan coğrafyasındaki Alevi halkın Emevi devletine vergi vermeyerek topladıkları vergi ve zekâtları her sene Medine'deki İmamlara ulaştırdıkları, Peygamber evlatlarıyla yakın temasta bulundukları bilinmektedir. Bu durum Emeviler dönemi dışında Abbasiler ve Selçuklular döneminde de devam etmiş, İranlılar Mekke ve Medine'de yaşayan Şürefa ve Sâdât'a humus ve zekâtlarını taşımış, mevcut hükümetleri görünürde kabul ederek tüm hukukî meselelerini bu zevatlara intikal ettirerek sorunlarına çare aramışlardır. $\mathrm{Bu}$ durum İranlıların öteden beri hac dışında da Haremeyn coğrafyasıyla sıkı bağlar kurduğunu göstermektedir. (İrfanmeneş,1374:109; Amuli,1368: 162).

Şii Müslümanların Sünni dünyanın kalbine yapacağı hac yolculuklarıysa beklenilenin aksine tarihin hiçbir döneminde kesintiye uğramamıştır. Sünni-Şii çatışmalarının arttı̆̆ Safevî döneminde bile bu ibadetin kesintisiz olarak yerine getirildiği görülmüştür. Mesafenin uzaklı̆̆ı, güzergâhların Sünni topraklardan geçmesi gibi zorlukların İranlıların hac kararını etkilemediği bilinmektedir. Safevîlerin bu ibadetle bağlantılı olan en önemli özelliği; gidişte, özellikle de dönüşte Muharrem etkinliklerine katılmak üzere hacla Atabât ziyaretini birleştirme arzusudur. $\mathrm{Bu}$ arzu, kişinin tek seferde hem hacı hem de 
Kerbelâi olma isteği ile alakalıdır. Atabât'a daha önceden giden Acem hacılar bile bu şerefe tekrar nail olmak isterken ömründe bir kere hac yolculuğuna çıkacak olanların güzergâhlarını Atabât'a göre ayarlaması Şii rivayetlerde yer alan "Atabât ziyaretiyle haccın kemale ereceğine” dair bir kabulden ileri gelir (Vahidi, 1386:423). Bu kabul Irak’a oldukça sapa ve uzak olan kuzey ve batı eyalet hacılarının bile çoğu zaman güzergâhlarını Atabât'tan geçecek şekilde belirlemesine yol açmıştır. Bu anlayış Osmanlı hacılarının Kudüs ziyaretini haccın tamamlayıcı bir unsuru olarak görmesiyle mukayese edilebilecek bir olgudur (D.Turay, 2018: 126).

Burada belirtilmesi gereken en önemli husus bazı tarihçilerin Atabât ziyaretçilerini de hacı olarak görme, Atabât ziyaretleri için de hac terimini kullanılma ısrarlarıdır. Osmanlı resmi belgelerine bakıldığında bu yolcular için hacı ve zâir (ziyaretçi) terimlerinin ayrı ayrı kullanılmış olduğu, ziyaret mahalli zikredilerek kişinin nerenin zâiri olduğunun belirtildiği halde bazı tarihçilerin ziyaretçiler için hacı tabirinin kullanılmaya devam etmesi talihsizliktir².

Safevîlerin Şii olmasından ötürü mantıksal bir çıkarım yaparak kendilerine karş1 derin önyargıların yer aldığı tehlikeli Hicaz seferleri yerine Atabât ziyaretlerine önem vererek bu ziyareti hac gibi gördüklerine dair görüşler ${ }^{3}$ şüphesiz tekrar gözden geçirilmeye muhtaçtır. Atabât ziyaretlerine ilginin yoğunluğu, buranın coğrafî olarak kendilerine çok daha yakın olması, seyahat masrafları açısında daha ucuz oluşu, dönemin şartları ve hacca gidişin oldukça masraflı ve tehlikeli oluşu gibi tabi etkenlerle alakalı olup, Mekke ve Medine'ye gidemeyen çoğunluğun hiç değilse Peygamber evlatlarını ziyarete gitme istekleriyle açıklanabilir. Acemlerin eğitim ve öğretim gördükleri, akrabaların birbirleriyle gidip geldiği, etle tırnak mesabesinde olan, aynı zamanda geniş sınırlara sahip Irak topraklarına yapılan ziyaretlerle hac ziyaretlerinin kıyaslanması bu manada mantık dışıdır. Atabât ziyaretlerinin itikadi anlamda hac ziyaretlerinin yerini almadığı, günümüze kadar yazılan tüm Şii fikıh kitaplarındaki müstakil hac bölümlerinden de anlaşılmaktadır. ( Hilli, 1353, C1/290: Amuli, 1380: C.1/7; İlm'ul Huda, 1379; 208). Safevî dönemi gibi Şiiliğin mezhepleştiği bir dönemde bile İranlı hacılardan yol bulanın hacca gitmesi (Ali İmran/97) çağrısına uydukları, farz/vacip ${ }^{4}$ olarak gördükleri bu ibadeti yerine getirmek için canlarını tehlikeye atan yolculuklara çıktıkları bilinmektedir.

Safevî döneminde İranlıların Hicaz'la ilişkilerinin devam ettiği görülür. Bu dönemde Acemlerin hac ibadetine verdiği değeri, Osmanlı'nın Bağdat'ın 914/1508 y1lında Şâh İsmail

\footnotetext{
${ }^{2}$ Süreyya Faroqhi'nin eserinde "I İki haccı birleştirmek" olarak alt başlıkla yorumlanan algı bu sebeple oldukça sathi ve derinliksizdir. (Faroqhi,1995: s. 152 ) Bu yanlış alg1 "İngiliz Kayıtlarında Aleviler Ve Bektaşiler" adlı makale de görülmekte " Kerbelâ'ya hacı olmaya gider ve Kerbelâ'da hac ibadetini yaparlar" şeklinde ifade edilmektedir (Beşe ve Tozlu.2011:215).

3'Şiiler için Kerbelâ'da Meşhed Hüseyin' 'in ziyaretinden önce Ka'be'ye hac ziyaretleri mümkün değildir, bir defa hacca gitmiş olanlar dahi iki senede bir Kerbelâ'y ziyaret ederek en mukaddes dinî vazifeyi yerine getirmiş olmaktadırlar" diyen Jülide A.Orat coğrafi önceliğe sahip Atabât ziyaretini hac ziyaretinin önüne geçirerek bu anlayışın dini bir kaygıdan ileri geldiğine işaret etmesi düşündürücüdür (Orat, 2014: 62-73).

${ }^{4}$ Bu konuda yanılgılara yol açacağı düşünülen bir nokta da haccın Şiilerde "Vacip" olmasıdır. Vacip terimi Şii terminolojide "Farz" anlamına gelir. (Beygleri, 1340: 118) .
} 
tarafindan kuşatılması ardından haccı İranlılara yasaklaması hadisesinde bariz olarak görebiliriz. Buna göre yasağa misilleme yapan Safevî Devleti'nin gösterdiği tepkiye halk aldırış etmemiş, Atabât ve hac ziyaretlerini yasaklayan ve bunun yerine Meşhet’teki İmam Rıza'nın (ö.819/1416) makamını ziyarete davet eden Şah’ı dinlememişlerdir. Neticede her iki taraftan yani hem Osmanlı devletinin yasaklaması ve hem de buna tepki olarak Safevî Devleti’nin hacıların gidişlerine mani olması ardından korumasız kalan, can güvenliği olmayan hacılar bu karara karşı koyarak Hicaz'a gitmeye devam etmişlerdir. Burada Şâh Abbas'ın (ö.1039/1629) hacıları düşündüğü için değil de ülkede azaldığı bilinen altın ve gümüşün Osmanlıların cebine gitmemesi için aldığı yasak kararının bir bahane olduğu bilinen bir gerçektir. Öte yandan kararın halkın Şâh'a olan itimadını zedelediği, nefreti arttırdığ 1 bilinmektedir. (Felsefi, 1347:201) Nitekim bu dönemde birçok âlim ve devlet adamının yasağa ve güvenlik anlamında önlerini görememelerine rağmen Şâh'a Pişkeş diye tabir edilen rüşvet vermek suretiyle yol emri/izni satın alarak hacca gittiği kaydedilmiştir. (Doğan, 2012:118). Yasağın sert bir şekilde eleştirildiği görülmüş, Safevî müverrihlerinden Natanzi'nin eserinde Kayıtbay'la (ö.902/1496) Uzun Hasan'ın (ö.883/1478) şiddetli mücadeleleri zamanında bile haccın kesintisiz olarak devam ettiği zikredilerek yaşanan Bağdat kuşatmasının bundan daha geçici ve hafif olduğu dile getirilmiş, karar anlamsız bulunmuştur (Natanzi, 1373:416).

Şâh Abbas'ın böyle bir teklifi dile getirmesi, içinde bulunduğu gelenekten çok da uzak olmayan bir kabulle alakalı olduğu düşünülebilir. Nitekim bu emir daha önce Şâh İsmail tarafından da gündeme getirilmiş, halkın hacdansa Irak'taki Şiî imamların türbelerine gitmeleri istenmiştir (Lapidus, 2002:408). Bu kararı yakın zamanda değişen Alevi inancının bir kalıntısı olarak görme başka bir araştırmanın konusudur. Fakat Alevi inancında yer eden ve günümüzde devam eden düşüncede ömürde bir sefer Meşhed'i ziyaretin Mekke ve Medine'den daha makbul olduğu, Horasan hacisinin asıl hacl olarak kabul edildiği bu noktada düşündürücüdür. (Beşe ve Tozlu, 2011:217). Bu kabulün İran kültüründeki "Fakirlerin haccı Meşhet”tir şeklindeki kültürel ve mecâzi kabulden ileri geldiği düşünülmektedir. Öte yandan bu düşüncenin Safevî Devleti'nin manevi kurucuları arasında uygulanmadığı, Safiuddin Erdebili'nin (ö.735/1334) 85 yaşında hacca gittiği, oğlu Şeyh Sadreddin'in 87 yaşında babası gibi hac dönüşünden hemen sonra 1392 yılında vefat ettiği bilinmektedir. (Ekinci, 2010:144-147), Şeyh Sadreddin'in halifesi Hace Ali Siyahpuş'un ömrünün sonlarına doğru hacca giderek 1427 y1lında büyük bir mürit topluluğu ve oğlu İbrahim'le beraber Mekke'de bir süre ikamet ettiği, İran tarihçisi Handmir'e göre burada öldüğü bilinmektedir (Handmir, 1380:C III.3,423). Buradan Hac ve Atabât'ın yasaklanarak Meşhed'in halka tavsiye edilmesinin asıl sebebinin siyasî olduğu, kararın gelenekten gelen zayıf bir rivayete dayandırıldığı sonucu çıkarılabilir.

$\mathrm{Bu}$ yasak ve engellemelerin tersine bir siyaset geliştiren II. Şâh Abbas'ın (ö. 1077/1667) böylesine tehlikeli bir kararı telafi etmeye çalıştığ 1 , hacca ve bilhassa hacıların korunmasına önem verdiği, bu sebeple Mekke Şerifi'yle temaslarda bulunduğu görülmektedir. Buna göre II.Şâh Abbas'in Mekke Şerifi'ne haber yollayarak geçen sene hacılara yönelik yollarda yaşanan saldırılar nedeniyle bu sene onları göndermeyeceği tehdidinde bulunduğu, ancak emniyetin sağlanması durumunda hacıların yola çıkmalarına izin vereceği duyurulmuştur. Bunun üzerine Basra hâkiminin karardan endişe duyarak hac mevsimi öncesinde Acem kervanlarına hareket izni verilmesi isteği ile Şah'a adam gönderdiği, Basra hâkimine güvenmeyen Şâh'ın, Mekke Şerifi'nden kendi hacılarının can ve mallarını koruması için yardım istediği bilinmektedir., Şerif'e her hacıdan 5 sikke alınarak 
kendisine göndereceğine dair söz veren Şah, hacıları korumakla tarafeyn arasındaki muhabbetin kök salmasını arzuladığını ifade etmiştir. (Caferiyan,1383: s 279). Hicaz'da Osmanlı halifesini görmezden gelen ve Mekke Şerifi'ni muhatap alan bu tür davranışların Safevî hâkimlerince sıklıkla tekrar edildiği bilinmekte, Şah'ın Mekke ve Medine'deki Sâdât ve Şürefa ile hem siyasî hem dinî yönden ilişkiler kurduğu görülmektedir. Öte yandan bu ilişkilerde Hüseynilik ve Ehlibeyt muhibliği gibi müşterek esasların ön plana çıkarıldığı, mezkûr olaydaki gibi Safevî Şâhı'nın mevcut dostluğu kullanarak Basra yoluyla gelen hacıların korunmasında önlem aldığı anlaşılmaktadır.

\section{Safevî-Osmanlı Siyasetinde Acem Hacıları Sorunu}

Günümüz Irak, Bahreyn, Arabistan, Yemen, Hicaz, Lübnan ve Suriye gibi ülkelerde bulunan ve Şiiler için önemli olan birçok ziyaret mahalli ve bu mahallere giden tüm kara güzergâhlarının Safevîler döneminde Osmanlı eyaletlerinde olduğu düşünüldügünnde Acem hacı ve ziyaretçilerin iki ülke siyasetini belirleyen faktörlerden biri olduğu anlaşılır. İranlılar için Osmanlı topraklarına seyahati zorunlu hale getiren bu durum, Safevî veziri Mustovfi elMemalik'le (ö.1299/1882) dönemin siyasî simalarından Gulam Rıza Han Şihabü'l-Mülk (ö.1294/1878) arasında geçen diyalogda mizaha dönüşür. Buna göre Vezir, Şihabü'l-Mülk'e sürgün yeri olarak Atabât, Horasan ve Mekke olmak üzere üç yeri önermiş, o da kararını bildirerek birçok kişinin sürgün yeri olarak Mekke'yi seçtiği, kendisinin de zaten hacca niyetli olduğu, ömrünün geri kalan kısmını geçirmek üzere buraya gideceğini söylemiştir. Mustovfi el-Memalik, İstanbul ve Bağdat yolundan gitmesinin tehlikeli olacağını bildirerek, kendisine başka bir güzergâh seçmesini önermiştir. Şihabü'l-Mülk bu sözüne gülmüş, Mekke'ye giden tüm yolların Osmanlı topraklarından geçtiğini hatırlatarak "En iyisi siz benim için izin sadır buyurun da havadan Mekke'ye gidip geleyim!" şeklinde latifede bulunmuştur (Senendeci,1375: 348, Doğan, 2009:167).

Acem hacıların Kanuni Sultan Süleyman döneminde bu mecburi istikametlerinde genel olarak rahat yolculuklar yaptı̆̆ 1 , bu dönemde güzergâh üzerindeki hâkimlere verilen kesin emirler sayesinde tüm Müslümanlar gibi hacca rahatça gidip geldikleri görülür. (Felsefi, 1347: 242). Daha sonraki dönemlerde ise bu durum değişmiş, iki ülke arasında yaşanan siyasi ve iktisadi sorunlar yüzünden Bağdat yolu kendileri için güvensiz hale gelmiştir. Şam güzergâhından hacca gitmeleri istenmiş, bu yönlendirilmeler zamanla istek ve tavsiyeden çıkarak 1021/1612 Nasuh Paşa Antlaşması'yla yaptırıma dönüşmüş, kati suretle Bağdat ve Basra yolu bu hacılara kapatılmıştır (Sibai,1999:C II/ 436). Bu durum Mağripli Ebu Müslim Muhammed Ayyaşi’nin 1072/1662 yılı haccından bahsettiği eserinde şöyle dile getirilir: "Iranlı hacıların Sultanına İan Şâhı denilir ki İsfahan, Irak-ı Acem ve Mâverâünnehir'de hâkimdir. Şâh'in muhafizları Osmanlının hâkim olduğu Irak bölgesine giremediği için Bağdat-Küfe-Basra'dan, Irak kafilesi ile gelenler Şam'da Osmanlı denetiminde girerler ve korunakl bir şekilde Mekke'ye ulaşırlar”.'(Emhazun, 1985:188).

Safevî tarihi boyunca Bağdat'ın kaybedilmesiyle on beş yıl süren olay ve dönemler dışında, Acemlerin kesintisiz olarak hacca gittiği görülür. Nitekim Safevî hacıları, 1047/1637 Bağdat kuşatması sonrası IV. Murat'ın Basra'dan Mekke'ye giden yolu yasaklamasıyla başka güzergâhlara yönlendirilmiş, 1638'de Mekke'den çıkarılmalarıyla uç noktalara ulaşan olaylarla bu hacılar zor günler yaşamışlardır. (Cutillas, 2016,38). Kendileri için Şam güzergâhının tayin edilmesi batıda fetihlerle meşgul olan Osmanlı devletinin doğusunda emniyeti sağlama çabasıyla alakalıdır. Osmanlı devletinin hacıların maslahatı için aldığı bu 
önlem, karar ve kısıtlamaların işe yaradığı, diğer gayrı resmi güzergahlara nazaran bu yolda hacıların can ve mallarının güvenceye alındığı zamanla ortaya çıkmıştır. (Caferiyan, 1371: C 14/38).

Öte yandan Osmanlı padişahının kara ve deniz yoluyla Mekke'ye giden tüm hacıların hamisi, harisi ve hadimi olduğu gibi Acem hacıların da koruyucusu olduğu, Arap ve Acem meliklerinin efendisi olarak kabul edildiği görülmektedir. (Osmanlı Belgelerinde Surre Alayları, 2010:389). Bu kabulün Osmanlı Sultaları için meseleyi daha da hassas hale getirdiği, bu sebeple devlet yetkililerini hem hacıları ve hem de kendi halkını korumak adına Anadolu ve Irak'ta taraftar toplamak için gezen Erdebil Tekkesi ve Şâh'ın dâilerinin hacılar arasına karışmasını önlemek için azami çaba sarf ettiği bilinmektedir. (Dalkesen,2005, 11/42, 15). Nitekim 27 Cemaziyelahir 976 tarihli bir resmi belge bize Şam ve Halep'e gelen Safevî tüccarlarının Rafızî olduklarını, takip edildiklerini, bunların hacıların arasına karışarak rahat hareket edebilecekleri endişesiyle hacı kafilesine alınmadıklarını gösterir. (BOA, MD 7/I, s.319 ) Bir başka belgedeyse Acem hacıların mezkur sebeple halkın evlerinde değil de şehir dışında su kaynakları yakınında konaklamaları ya da yol üzerindeki kervansaraylarda kalmaları emredilmiş, ayrıca Safevî tebaasındaki bazı şahısların hacı sıfatıyla ticarî faaliyette bulundukları fark edilip bunların önü alınmıştır. (BOA,23 MD7/III, s.203). Fakat sızmalara karşı alınan bu sıkı tedbirler salt dinî hislerle seyahat eden çoğu Acem hacısının 1ssız yollara yönlendirilmelerine, dinlenme ve erzak gibi hayati ihtiyaçlarını karşılayamamalarına sebep olmuş ve onları zor durumda bırakmıştır (Sefernâmey-i Manzum-i Hac, 1374: 86).

Acem hacıların Anadolu güzergâhlarındaki sorunlarına dikkatle bakıldığında asıl sorunun yerli halkın tutum ve davranışıyla ilgili olduğu görülür. Zira bu dönemde yazılan seyahat notlarında yaşandığı kaydedilen kervan baskınları, bu baskınlardaki can ve mal kaybının güzergâhtaki hâkimlerin başına buyruk hareketleri ve cahil halkın Şii hacılara fütursuz davranışlarından kaynaklandığı anlaşılır. Bu olayların özellikle Erzurum-Urfa güzergâhında itaatsiz aşiretlerin daimi tacizleri neticesinde meydana geldiği, suçların sadece Anadolu'daki aşiretler tarafından değil de bazı dönemlerde Safevî hacıların can ve mallarını ganimet olarak gören İranlı Kızılbaşlar tarafından da işlendiği, eşkıyalık yapan bu şahısların kendi devlet hacılarına dahi kastlarının olduğu görülür. (Caferiyan, 1373:392). Nitekim Kızılbaşların 1510 yılında Anadolu'da Şâh Kulu (ö. 1511) - Hadım Ali Paşa (ö. 1511) mücadeleleri zamanında Sivas-Erzincan yolundan İran'a kaçtıkları sırada Acem kervanını soyarak hacıların mallarını yağmaladıkları, birçok insanı öldürdükleri bilinmektedir. (Nişancızâde, 1841:C/ 94).

Öte yandan Acem hacılara karşı Osmanlı tebaası ve hâkimlerinin hoşgörüsüzlüğünün dozunun iki ülke arasındaki siyasî ve dinî hareketlere bağlı olarak arttı̆̆ı müşahede edilmektedir. Bu durum şüphesiz Bağdat'ın kuşatılması, Azerbaycan bölgesinde yaşanan toprak kayıpları ve sınır ihlalleri, Şâh İsmail taraftarı Muhammed Han İstaclu'nun Diyarbakır ve Irak-1 Arap bölgesini işgali, Özbek Han'1 Şeybek Han'ın Safevîlerce katli, Şâh İsmail'in dinî esaslara aykırı bazı fikirler yayması gibi kini arttıran siyasî gelişmelerin yaşandığ dönemlerde daha belirgin hale gelmiştir. Bu hoşnutsuzluk sadece Anadolu'da Kızılbaşların takibi, mallarının tevkifi ve katliyle sonuçlanmamış, Acem hacıların sıkıntılı yolculuklar yapmasına da sebep olmuştur. Safevî zulmünden kaçan Sünni tebaanın özellikle ulemanın beyanları halkı bu hacılara karşı tavır almaya itmiş, 1514 Çaldıran savaşı ardından başlayan, İran, Herat ve Mâverâünnehir'de katledilen Sünni halk ve ulema için Rafizîlerin 
katlinin vacip olduğuna dair Şeyhülislam İbni Kemal ve benzeri ulemanın verdiği fetvalar durumu daha da ağırlaştırmış, sadece Anadolu'da değil Haremeyn'de de Osmanlı halkının Acem hacılara karşı öfke duymasını sağlamıştır. (Tekindağ, 1967: C.XVII, 2-53).

Anadolu dışında Haremeyn'de Acem hacılarına karşı yaşanan öfke, hacıların daha çok Sünnilere ait birtakım uygulamaları kabul etmemeleri sebebiyledir. Arife gününün tahakkuku hakkında diğer hacılarla ihtilaf yaşayan İranlılar, devletin Hacc-1 Ekber ilanını çoğu kere yerinde bir karar olarak görmemiş, bu da Mekke'de kargaşa doğmasına, kin ve nefretin vücuda gelmesine sebep olmuştur. Bu davranışlarına ek olarak cemaat namazlarına iştirak etmemeleri, farklı bir tarzda ihram bağlamaları da hoş karşılanmamış, haccın asıl hedefi olan dirliği ve birliği bozan hareketler olarak görülmüş, hacıların doğal olarak ötekileştirilmelerine sebebi olmuştur. (Doğan,1389:231-246). Buna ek olarak Safevîlerin sonunu getiren olay diye tabir edilen 1124/1712 Kandahar Muhasaras1 ve Afganlı Mir Üveys'in (ö.1132/1719) Mekke'ye giderek İranlıların Rafizî ve kâfir olduğu, kendileriyle savaşın farz olduğuna dair aldığı fetvalar Acem hacıların Haremeyn'deki durumunu daha da ağırlaştırmıştır ( I’tizadüssaltana, 1365:102). Neticede Mekke ve Medine'de Acem hacılara yapılan uygulamalara şahit olan Anadolu insanı kendi topraklarından geçen hacılara karşı duyarsız kalmış, bu ve benzeri birçok siyasî ve dinî sebep Osmanlı halkıyla Acem hacıları arasında derin bir düşmanlığa yol açmıştır. Bu yanlış algı Acemlerin para ve mallarına yeltenenler için birer bahaneye dönüşmüş, özellikle devletle bölge aşiretlerinin çıkarlarının ters düştüğü zamanlarda vahim sonuçlar doğurmuş, barış zamanında önü alınamaz olaylara sebebiyet vermiştir.

Osmanlı coğrafyasında Acem hacıların yaşadığı saldırı ve kötü muameleye misilleme yapılmış, Safevî coğrafyasından geçerek hacca gitmek zorunda olan Mâverâünnehir, Türkistan ve Hint hacılarının yolları kapatılmış, önceleri kara yolunu kullanarak Atabât ziyareti ardından Mekke'ye giden birçok Hint hacısı bundan böyle deniz yolundan gitmek durumunda kalmıştır. (Güler, 2016:C.18,1/ 3) $\mathrm{Bu}$ mağduriyet vakayinamelere ve Osmanlı resmi belgelerine yansımış, 976/1569 da Harezm Özbek hac kafilesi Safevî topraklarında alıkonulmuş, Özbek ve Safevî mücadelelerinin ivme kazandığı dönemlerde yollarını uzatarak Kuzey güzergâhlara yönelen bölge hacıları bu konuda Osmanlı Devleti'nden yardım istemişlerdir (K.Çınar, 2015: 75; Vambery,1380: 312).Bu tehlikeli hac yolculuklarından biri Cadde-i Aşıkin adıyla yakın dönemlerde yayımlanmıştır. Ülkemizde henüz tanınmayan bu eserin sahibi Semerkant Hüseyniyye Dergâhı şeyhi Hüseyin Harezmî' (ö.1539)dir. O, 945/1538 yılında Kanuni Sultan Süleyman döneminde hacca gitmiştir. Şeyh Hüseyin Harezmî’nin menakıp, makalât ve hac hatıralarına yer veren ve on beş bölümden oluşan eserinde kendisinin Harezm'den yola çıkarak uzun ve tehlikelerle dolu bir yolculuktan sonra İstanbul'a ve buradan da Mekke'ye gidişi anlatılır. Oğlu Kemaleddin Harezmî tarafından kaleme alınan bu hatıratta Şeyh ve müritlerinin Sebz, Karşı, Karagöl, Harezm, Semerkant, Buhara, Fethabad, Belde, Saracuk, Hacı Tarhan, Azak, şehirlerinden geçen güzergâhı takip ederek Kırım'a ulaştığı, burada Giray Han(ö.1577) tarafından sarayda ağırlandıkları görülür. Akkirman limanından gemilerle yola çıkan hacılar İstanbul'a gelerek Kanuni Sultan Süleyman'ın ilgisine mazhar olmuştur. İstanbul'dan Surre-i Hümayun eşliğinde kara yoluyla Şam'a giderek hac vazifesini yerine getiren Şeyh ve müritleri daha sonra Halep'e dönmüş; Şeyh, Halep'te vefat etmiştir. Bu örnek yolculuk ve seyahatname Safevîlerin Osmanlı'ya karşı misilleme siyaseti sonrası yollarını uzatan Mâverâünnehir hacılarının o günkü zorlu ve maceralı yolculuğuna şahitlik etmesinden ötürü oldukça önemlidir (Harezmî, 1390: 23). 


\section{Safevî Hacıların Resmî ve Gayrı Resmî Güzergâhları}

Safevî hacıları Osmanlı hacıları gibi her yıl ordu düzeninde giden kervanlarla yolculuğa çıkmayıp sabit güzergâhlarda yeniçeri korumasında yol almazlardı. Bu hacılar hayal edilemeyecek kadar zorlu ve sikıntılı yolculuklar yapar, her an can korkusu ve soygun tehlikesiyle karşı karşıya kalırlardı. Bu husus Mağripli Ebu Müslim Muhammed Ayyaşi’nin 1073/1662 yılı haccindan bahsettiği eserinde görülmekte, Acem hacıların bu zorlu yolculuklarına değinilmektedir. Ayyaşi eserinde o yıl Acem hacıların yollarda uzun süre kaldıklarını, kervanlarının ancak Sefer ayının ortasında Medine'ye ulaşabildiğini, bu hacıların İsfahan'dan Medine'ye gelirken Basra Hâkimi'ne haraç ödediklerini, bedevi baskınlarından korunmak için kişi başına elli dinardan fazla altın verdiklerini zikreder (Emhazun, 1985: 188).

Safeviler döneminde Acem ülkesinden gelen hacıların genel olarak üç kara güzergâhı kullandığı bilinmektedir. Bunların tamamı Osmanlı devleti tarafından gayrı resmi güzergâh olarak kabul edilmiştir. Bu güzergâhlardan ilki ve en çok kullanılanı Acem hacıların asıl ve tabii yolu olarak bilinen Irak güzergâhıdır. Birinci bölümde belirttiğimiz Atabât ziyareti sonras1 gidilen ve Derb-i Zübeyde yahut $\mathrm{Cebel}^{5}$ yolu denilen bu güzergâh, Bağdat'tan geçmektedir. Bağdat'ı ziyaret eden hacılar, Necd yarımadası içlerinden devam eden bu yolla Mekke'ye varmaktadırlar. Bu güzergâh Acem hacılar için hem en yakın ve eski hem de can ve mal kaybı ihtimalinin en çok yaşandığı yoldur. Bu sebeple resmi belgelerde güzergâh için "Kadîmden ilâ-yevminâ hâzâ olageldüği üzre mesdûd" ibaresi kullanılmış ve yolun tehlikelerden ötürü çoğu zaman kapalı olduğunun altı çizilmiştir (BOA, MD 6, s.44). Fakat birçok siyasî nedenle, en önemlisi de güvenli olmadığı gerekçesiyle yasaklanıp kapatılan bu yolun, tarihin her döneminde kesintisiz bir şekilde kullanılmaya devam edilmesi oldukça ilginç ve düşündürücüdür.

Acem hacıların ikinci yolu Basra güzergâhıdır. $\mathrm{Bu}$ yol daha çok kıyı şeridinde yaşayan Güneyli Arapların seçtiği yoldur. Ayrıca bu güzergâh o dönemde İran coğrafyasından ayırt edilemeyen Katif, Ahsa ve Bahreyn gibi Haliç bölgesi hacı adayları tarafindan da kullanılmıştır. Buna göre Bender Kong, Bender Buşehr ya da Bender Abbas limanlarından yola çıkan hacılar, Basra'ya gelir, kara ya da nehir yoluyla Atabât ziyareti yapar, ardından Cebel yoluyla Mekke'ye giderlerdi. Bu yolu kullanarak Basra'dan Necd'i ikiye bölen Beride-Nogre güzergâhıyla Medine'ye ulaşanlar da olurdu. Üçüncü gayrı resmi güzergâhsa Lahsa-Mekke yolu olup Basra körfezi limanlarından gemilerle Lahsa(Ahsa)'ya gelen hacıların bu yoldan Mekke'ye 20 gün gibi kısa bir sürede gittiği bilinmektedir. Nitekim Safevî âlimi Muhammed Taki Meclisi (ö.1071/1660) 1042/1632 yılında yapmış olduğu üçüncü haccında Lahsa güzergâhını kullanmıştır (Meclisi,1379: C.III/ 105).

Safevî hacılarının kara güzergâhlarına nazaran deniz güzergâhlarını daha az kullandıkları bilinmektedir. Hacılar bu dönemde İstanbul duraklı Karadeniz güzergâhı, Hindistan Surt Limanı çıkışlı Hint denizi güzergâhı gibi birkaç istisnai yol dışında Basra Körfezi'nden yola çıkan gemilerle Kızıldeniz'e ulaşmışlardır. Bu dönem her ne kadar hacılar için gemi yolculuklarında başlangıç sayılabilecek bir dönem olsa da her daim kullanılmış,

\footnotetext{
${ }^{5}$ Cebel kasabasından adını alan bu yoldan resmi ve gayrı resmi surette hacca gidişin tarihin her döneminde gidildiği görülür (Hatunabadi, 1369.:553).
} 
Venedik ve Portekiz korsanlarının Basra körfezindeki geçişleri kontrol altına aldığı korkulu dönemlerde bile gemiyle hacca gidilmiştir. Bu yolculuklardan birini Kirmanlı Muhammed Said Meşizi yapmıştır. Meşizi 1679 yılında dönemin en işlek limanı olan Bender Kong'dan yola çıkmış, Arap yarımadasını dolaşarak Maskat limanına gelmiş, Aden ve Moha limanlarını geride bıraktığı yolculuğunun ardından Gunfuza limanına gelerek Yulemlem'deki ihram noktasında ihrama girmiş, bu yolculuğunu Tezkire-i Safevîyye-i Kirman adlı eserinde anlatmıştır (Tezkire-i Safevî yye, 1369: 468).

Osmanlı devleti buraya kadar saydığımız üç kara güzergâhını yaşanacak muhtemel kayıplar sebebiyle yasaklamış, daha önce de belirttiğimiz gibi Safevî hacılarına resmi güzergâh olarak Şam-Mekke yolunu tayin etmiş, bu konuda kararlı olduğunu göstermek adına ahitnamede belirlenmiş olan hususu her fırsatta yazışmalarda dile getirmiştir. Bunlardan sadece biri 972/1565 y1lında Acem hacılardan sorumlu hâkimlere hacıların resmi usullerin dışına çıkmamaları için yapılan kati uyarıdır. (BOA, MD 6, s.44) Diğer taraftan bu güzergâhın İranlı hacıların Cebel yoluna göre daha rahat gidip gelebilecekleri, hiç değilse maddi kayıplarının ardına düşebilecekleri, bu konuda şikâyetlerini bildirebilecekleri bir yol olduğu açıktır.

Acemlerin bu üç güzergâhı kullanmayarak Şam yoluyla hacca gidebilmeleri için öncelikle Şam'a gelmeleri gerekmektedir. Oysa kendileri için Şam'a ulaşacak sınırlı sayıda yol mevcuttur. Bunlar arasında Atabât ziyareti ardından Musul ve Halep'ten geçen ve üst yol olarak tabir edilen Güneydoğu Anadolu güzergâhı sıklıkla kullanılmıştır. Bunun dışında Acem hacıların Şam'a ulaşmak için daha az kullandığı ve alt yol olarak tabir edilen, Tedmür'den geçen ikinci bir yol dahî bulunur. (Cantay, 2000:C 1/415). Bu iki güzergâh dışında bizim asıl konumuz olan ve İranlıların Anadolu-Şam yolu dedikleri Osmanlı'nın doğu vilayetlerinden geçen güzergâhsa saydıklarımız arasında en çok istifade edilendir. Bu yolu kullanacak Acem hacılarının Tebriz'de toplandıkları, Erzurum-Malatya-Urfa üzerinden Tedmür yoluyla Şam'a gittiği, bazı kervanlarınsa Hoy şehrinde toplanarak Van-Birecik-Urfa yoluyla Musul-Halep güzergâhına bağlanarak Şam'a vardıkları bilinmektedir. (Doğan, 1375:57/42). Buna göre 1514-1867 yılları arasında kullanıldığ d düşünülen bu yol, Osmanlı'nın Van, Çıldır, Kars, Erzurum, Diyarbakır ve Musul eyaletlerinden geçmektedir. $\mathrm{Bu}$ vilayetleri ardında bırakarak Halep'e ulaşan İranlıların Surre'nin denizden gönderilmeye başlandığ 1281/1863 senesine kadar Şam'a gelerek Osmanlı resmî hac kervanıyla Mekke’ye yol aldıkları var sayılır. (Atalar, 1991:123).

\section{Doğu Vilayetleri ve Safevî Hacıları}

Osmanlı'nın doğu vilayetlerinden geçiş Acem hacılar için payitahttan uzakta, kontrolü güç, dağlık ve güvensiz bölgelerden yapılacak korkulu bir yolculuk demekti. $\mathrm{Bu}$ coğrafyada Acem hacıların Safevî Devleti ile Osmanlı arasında sağlam bir duvar oluşturan aşiretlerin devletle ters düştükleri zamanlarda saldırıya uğramaları işten bile değildi. Nitekim bu vilayetlerde birçok defa Acem hacıların huzurunu bozan saldırılar gerçekleşmiş, saldırılar iki ülke arasında skandallara yol açmıştır.

Devlet resmi belgelerinde Acem hacı ve ziyaretçilerin doğu vilayetlerine girişlerinden itibaren gördükleri "Muamele-i Seyyie" diye tabir edilen kötü muamelenin sebebini anlamak için öncelikle bölgenin siyasî durumunun iyi anlaşılması gerekmektedir. Bölgenin 16.yy başlarından itibaren otonom yönetildiği, dört yüze yakın miri aşiretin eyalet 
sancak ve hükümet beyleriyle karmaşık bir yapıyla idare edildiği düşünüldügünnde devletin yaşanan bu gibi olaylarda fevri müdahalede zorlanacağı açıktır (Burkay, 1992:173). Öte yandan bu güzergâhlar 1049/1639 yılında yapılan Kasr-i Şirin antlaşmasına kadar SafevîOsmanlı hudut ihlallerinin sıkça görüldüğü geçişken bir yapıda olup saldırıların önlenmesi oldukça güçtü.

$\mathrm{Bu}$ bölgede yaşanan sıkıntıların aslında uzun süren Osmanlı-Safevî çekişmesinden kaynaklandığı, ayakta kalmaya çalışan aşiretlerin kendilerine has bir yapı oluşturarak devlet hâkimiyetini ortadan kaldırdıkları düşünülmektedir. Osmanlı doğu vilayetlerindeki aşiretlerin değil devleti, bir diğerinin otoritesini dahi kabul etmemesinin bu karışıklığ doğurduğu açıktır. (Xemgin, 1997:281). Yine Çaldıran Savaşı'ndan sonra Safevî-Dulkadiroğluları hâkimiyetinin sona ermesinin ardından devletin bu coğrafyada belli bir dönem halka itimat etmediği, dolayısıyla da Sünni Kürt aşiretlerini tam olarak yanına çekemediği göz önünde bulundurulduğunda buradan geçen Acem hacıların güvensiz yolculuklar yapacağı aşikardır. (Işıksel, 2012: 33/40; Kılıç, 1999: 127). Bu olumsuz şartlara rağmen devletle iyi ilişkiler kuran bazı Kürt aşiretlerin Acem hacıları korumak ve diğer vilayete geçirmekle vazifelendirildikleri takdirde onları canları pahasına koruyarak sağ salim Halep'e ulaştırdıkları görülmektedir (BOA, MD7/I, s.39). Nitekim 1106/1694 yılında Acem hacılardan alınan haksız paralar yüzünden Emir-i Hac'cın yerine bir Kürt beyi tayin edilmiş, bu yeni Emir-i Hac Acemlerin mal ve paralarını iade ederek onları Halep'e ulaştırmıştır (Mehmet Paşa, 1977: C III/478). Fakat karışıklığın peyderpey devam ettiği,'Urban taifesi' denilen Kürt sancak beylerine muhalif olan eşkıyaların, hac kervanı baskınlarını yaşam şekli haline getirdiği birçok resmi belgede geçmektedir.

Safeviler döneminde Anadolu'daki bu baskınların varlığını destekleyen manzum bir hac seyahatnamesi mevcuttur. Sefernâme-i Hac adlı bu eser Erzurum-Erzincan yolundaki eşkıyaların hacıların korkulu rüyası haline geldiğine işaret eden bir kaynaktır. (Sefernâmey-i Manzum-i Hac,1374: 57). Mezkûr seyahatname Safevî hanedan üyesi Ordubad'lı Türk bir kadın tarafından yazıldığı için hac edebiyatı içinde müstesna bir yere sahiptir. Her ne kadar kendinden önce Şehzade İsmail Mirza'nın(ö.1577) annesinin hacca gittiği bilinse de bu şahsın eserinin bulunmamasından ötürü seyahatname alanında önem arz eder ${ }^{6}$. Anadolu yolunun tehlikeleri hakkında önceden uyarıldığını zikreden müellif, buna aldırış etmeden yola çıktığını, sağ salim Şam menziline ulaştı̆̆ında ise Osmanlı resmi kervanında korunaklı ve mahsus bir konumda seyahatine devam ettiğini bildirir. 1110-1130/1699-1718 y1lları arasında yaptığı bu yolculukta Erzurum-Urfa-Halep güzergâhını kullanan yazar, güzergâhla ilgili kendinden sonra hacca gidecekler için sıkça uyarılarda bulunur. Eserde verilen bu bilgilerin resmi belgelerde bahsedilen sıkıntılarla birebir olduğu görülür (Doğan, 2012: 35).

Şâire'nin İsfahan'dan başladığı yol İran güzergâhında Kaşan, Kum, Save, Kazvin, Sultaniye, Zencan, Miyane, Tebriz, Ordubad, Nahçivan, Erivan gibi şehirlerden geçer. Osmanlı topraklarına Kars'tan giriş yapan kafile daha sınırdan girer girmez Karaçay nahiyesinde Rumilerin saldırısına uğrar. Bu saldırıları olağan karşılayan hacıların burada dört gün alıkonulduğu görülür. Erzurum'da oturak eylemesi gereken kafile şairin diliyle "intikam

\footnotetext{
${ }^{6}$ Şehzade İsmail Mirza'nın annesinin hacca gittiği Osmanlı resmi belgelerinde yer alırken onun dönüşte Kerbelâ'da rahatsızlandığı, burada bir müddet kaldığı görülür. 3 Recep 972 tarihli Bağdat Beylerbeyi'ne gönderilen belgede tedbir amaçlı olarak Şâh'ın eşinin maiyetindekilerin bir kısmının İran'a gönderildiği, kalanların ise takip edildiği bildirilmektedir (BOA, MD 6, s.313)
} 
peşindeki Rumilerin” korkusu sebebiyle yoluna durmadan devam ederek, nihayet Erzurum ve Erzincan mevkiine varır. Bu bölge Karakoyunlu ve Akkoyunlu çatışmalarında viraneye dönen yerlerden biri olarak Safevîlere dolayısıyla bu hacılara karşı düşmanlığın zihinlerde henüz diri olduğu bir bölgedir. Aynı zamanda bu bölge 16. yüzyılın başlarındaki baskın ve istilalar sebebiyle garba doğru kaçarak gelen Sünni Safevî vatandaşların yerleşim bölgeleri olmas1 sebebiyle muhtemel intikam mahalleridir (Köse, 2009,76). Erzurum ve Erzincan da özellikle de Mama Hatun gibi hacıların mutlaka durması gereken, erzak ve yol ihtiyaçlarını karşılayarak yola devam etmeleri adet olan yerlerde kervanın baskın korkusuyla durmadan yoluna devam ettiği anlaşılır. Eserin devamında hacıların Mama Hatun'a iki fersah ötede büyük bir yıkıma uğradığı, her birinden doksan tümen istendiği, vermedikleri takdirde gitmelerine izin verilmeyeceği söylenince hacıların buna karşı koyduğu anlaşılmıştır. (Sefernâme-i Manzum-i Hac, 1374: 43). Çıkan çatışmada hacılardan bazıları öldürülmüş, Acılar Gölü adlı menzilde şâirenin değimi ile "Acılarını yıkayan” hacılar buradan Erzincan'a ulaşmıştır.

Eserde Acem hacıların Ĕgin adlı menzilde sabahladıklarında geceleyin mahir hırsızlar tarafından ceplerinde dönecek paraları kalmayacak biçimde soyuldukları zikredilmiş, (Sefernâme-i Manzum-i Hac,1374,54) Malatya'ya gelen hacıların uyarıldığı, buranın güzergâhın en tehlikeli geçidi olduğu söylenmiş, bu menzilde tedbire ve çarpışmaya davet edilmişlerdir. Zira burası Osmanlı resmi belgelerinde de değinilen hacı ve ticari kervanların onlarca kez soyulduğu Akçadağ mıntıkasıdır. Nitekim şâirenin seyahatine yakın tarihli bir başka resmi belgede 1277/1861 yılında Acem hacılarını taşıyan kervanın Akçadağ eşkıyası tarafından tam da bu mahalde soyulduğu görülür (BOA, A\{MKT. MHM. 192/2) Eserde Antep’te iki gün konakladıktan sonra Halep'e ulaşan Acem kervanının güvenli bir şekilde Şam'a kadar götürüldüğü ve buradan Mekke'ye ulaştığı zikredilir. Bu kaynak Osmanlı resmi belgelerde de görüldüğü üzere doğu vilayetlerinin Acem hacıları için bu dönemde ne kadar tehlikeli olduğuna dair bir delildir.

\section{Osmanlı ve Safevîler arasında Acem Hacıları Krizi ve 1123/1712 Olayları}

Safevî Sultanlarının Acem hacıların can ve mal güvenliğini korumak için Osmanlı sultanlarına birçok kere mektuplar gönderdiği bilinmektedir. Buna göre Şâh Tahmasb (ö.1576) Kanuni Sultan Süleyman'a yazdığı mektupta hacıların emniyet ve huzur içerisinde gidip gelmelerinin temin edilmesini istemiştir. Yine Şâh Tahmasb'in oğlu, Şam'a ulaşan Acem hacılara kolaylık gösterilmesi talebiyle Rüstem Paşa'ya mektup yazmış, bu mektupta konukseverliğin gösterilmesi halinde Acem hacıların Osmanlı padişahının sağlığına duacı olacağını belirtilmiştir (Nevai, 1368:264, 283 ). Bu istek yalnızca mektuplarla iletilen bir temenni olarak kalmamış, iki ülke arasında imzalanan 1590 Ferhat Paşa, 1612 Nasuh Paşa ve 1618 Serav antlaşmalarıyla gündeme gelmiş, Acem hacıların korunmaları için adım atılmış, Osmanlı doğu sınırına yeniden gelen barışın göstergesi olarak hacılar hakkında caydırıcı kararlar almıştır. (Küpeli,2014:126) Bu kararlarla devlet hac mevsimi öncesi Şirvan, Gence, Tiflis, Tebriz, Kars, Van, Çıldır ve Erivan, Erzurum, Diyarbakır, Halep, Şam, Şehr Zor, Humus Beylerbeyi, Sancak Beyleri ve hâkimlerine fermanlar göndererek Acem haciların vilayetlerden sağ salim geçirilmelerini istemiş, özellikle de Van ve Şehr Zor gibi eşkiyalığa açık stratejik geçiş mekânlarındaki beylerbeylerine, bu hacıların muhafazaları konusunda kesin uyarılar gönderilmiştir. 
Safevîler zamanında Şâh Hüseyin dönemine gelindiğinde (1694-1722) Acem hacıları için oldukça zorlu günler başlamış, hac mevsiminde Anadolu'daki güvenlik ihlalleriyle alakalı şikâyetler sıç̧a devlete bildirilmiştir. Bunun sebebi İran'da 1650-1770 tarihleri arasında yaşanan mali krizde devletin hacılarıyla yeteri kadar ilgilenememesidir. Zira bu dönemde var olan bu krize Afganlı Mir Üveys'in 1708 yılında İran'da bağımsız bir devlet kurması, 1720 yılında Osmanlı yönetimindeki kuzeybatı Kürdistan emirliklerinin Hemedan'a ilerlemesi gibi daha birçok olumsuzluk eklenince Acem hacıların Anadolu'daki yolculukları daha da zorlaşmışırı. Devlet ülkesi dışında hakları yenen tebaasını koruyamaz hale gelmiş, Acem hacılarıysa kendi çabalarıyla şikâyetlerini Babıâli'ye bildirerek Osmanlı Devleti'nden medet ummuşlardır.

Aşiretlerin kanlarını helal gördükleri bu hacılara saldırıları, her ne kadar devlete mal edilemezse de Safevî Devleti'ne karşı cevap merciinin hükümet olduğu açıktır. Bu durum en iyi Safevî Devleti Divan Emiri Masum Bey'in 976/1569 Anadolu üzerinden hacca giderken katledilmesi skandalında görülür. Masum Bey'in barıș zamanında, elinde hac ruhsatı/izni olduğu halde katledilmesi kısa zamanda siyasi bir krize dönüşmüştür ${ }^{7}$. Kazvin'den yola çıan Masum Bey, Van'dan Anadolu'ya girerken Van Beylerbeyi'ne emanet edilmiş, iyi bir şekilde karşılanması sağlanmıştır (BOA, MD 7/III, s.410) Anadolu'dan geçişi esnasında ise İran yanlılarıyla işbirliği yapma ihtimali üzerinde durularak güzergâhtaki hâkimlerden kendisine devletin behemehâl savaşa hazır olduğu intibası vermeleri istenmiştir. (BOA, MD 7/III, s.264; BOA, MD 7/II s.259) Diyarbakır'dan Halep'e buradan da Şam'a gidecek olan küçük kafilesinin seferi için yerel hâkimler teyakkuza geçirilmiş, sonunda kafile să̆ salim Şam'a ulaştırılmıştır. Fakat Masum Bey ve beraberindeki 48 kişi Mekke yakınlarına geldiğinde bedevilerce katledilmiştir. Bu karmaşık ve siyasî olay o dönem Şam Valisi'ne mal edilerek iki ülke arasında çıkacak daha büyük bir krizin önü alınmıştır. (Munşi,1350:C. 1/190). Devletin Şam Vali'sini görevden aldığı bu olayda hacıların muhatapları olan hâkim ve aşiret emirlerinin vazifelerinin oldukça kritik olduğu görülmektedir (Senendeci, 1375:347). Yöneticiler arasında bu tip saldırılara göz yuman, ortak olan, hatta el altından destek vererek görevini kötüye kullananların olduğu resmi belgelerde açıkça görülmektedir. Masum Bey olayının arka planında da böyle karmaşık ve özel durumun olup olmadığı farklı bir araştırma konusu olsa da acı sonla biten bu tür hadiseleri yalnızca güzergâhtaki Arap, Kürt ve Türk aşiretlere mal etmek; asıl sorunu görmezden gelmeyle eşdeğerdir. Acem hacılara karşı barış zamanında yapılan bu tür haksız saldırılar kınansa da devletin, sorunlara daha kesin bir çözüm getirmesi beklenmiş, fakat bu devletin içinde bulunduğu sıkıntılar ve Anadolu'da uzun süren Celali isyanları sebebiyle bir türlü mümkün olmamıştır (Melikoff, 1998: 226).

Safevî hacıların sorunları ve şikâyetlerinin ne ölçüde ve ne sıklıkta Osmanlı sarayına yansıdığı, ne keyfiyetle çözüme kavuşturulduğu resmi belgelerde etraflıca yapılacak bir araştırma sonrasında ortaya çıkacak başka bir çalışmanın konusudur. Fakat biz burada

\footnotetext{
${ }^{7}$ Masum Bey'in elinde olan Emr-i Rah, Ícazetname-i Rah denilen bu belge o gün Safevî hacılarının ülkede seyahatleri boyunca yanlarında bulundurdukları bir çeşit izin belgesi/pasaporttur. Hacıların bu belgeyle muhafaza, iaşe, ibate ve binek gibi ihtiyaçları meşru yollardan karşılanmakta, özellikle hacı adayları arasındaki devlet adamlarına bu belge ile karşılama ve uğurlama merasimleri uygulanmaktaydı (Doğan, 1397,49).
} 
derinleşen olaylardan yalnızca birine, 1123/1712 yılında Acem hacılara emir tayin edilen Acem Ağa'sının bölgedeki hâkim ve eşkıyayla işbirliği yaparak hacıları zor durumda bıraktığına dair bir belgeye değineceğiz.

1123/1712 yılına ait bu belge aslında Erzurum-Urfa-Halep güzergâhını kullanan "Huccac-l Acem"in dilinden yazılan bir arzuhaldir (B.O.A, C.HR. 1128). Belgede Beytullah'il Haram'ı tavaf için vatanlarından çıkan ve Acem vilayeti sınırında Erivan'a gelen hacıların Beyazıt toprağına ulaştıkları sırada Erzurumlu Ahmet denilen şahsın Erzurum ahalisinden bir kısmını yanına alıp sabah vaktinde hacıların üzerine hücum ederek para ve

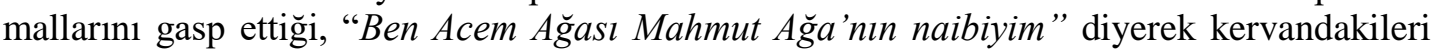
büyük zarara uğrattığı zikredilir. Mahmut Ağa denilen bu şahsın Divan Çavuşuyla birlikte Bitlis kasabasına gelen hacıların peşine Erzurum ahalisinden bir kısmını yollayarak, Bitlis hâkimi Adil Han'la işbirliği yaparak yedi gün boyunca kervanı alıkoyduğu, Acem Ağası'nın adını kullanarak hacıları soyduğu anlatılır.

Belgenin devamında Adil Han ve adamlarının selametiyye ve pişkeş namıla hacıların yüklü miktarda para ve mallarını aldıktan sonra gitmelerine izin verdiği, bu şahsın emini Kürt Kasım Ağa ve adamlarını onların üzerine yolladığı ifade edilir. Hacıların Deliklitaş adlı yerden geçişleri esnasında Kasım Ağa'nın kervanı durdurarak zengin fakir demeden değnek zoru ile her bir nefer başına üçer altın aldıktan sonra kervana yol verdiği, bununla da kalmayarak tüm mallarını hatta bir köşede sakladıkları ilaç paralarını dahi yağmaladığı, ardından kendilerini yine Adil Han'ın kardeşi olan İshak adlı şahsa teslim ettiği bildirilir. İshak'ın kendilerini dört gün alıkoyarak soyup soğana çevirdiği, daha sonra kişi başına ikişer altın alarak hacıları ters istikamete gitmeğe mecbur ettiği, ardından da Şirvan Bey'ine gönderdiği, onun da kendilerine zulüm ederek altı gün boyunca alıkoyduğu, selametiye vergisi diyerek yığınla akçelerini aldığı, burada kişi başına ellişer altın ödedikleri, hac kafilesinde at, katır, eşya her ne gördüyse gasp ettikten sonra Acem ağası Mahmut Ağa'nın talimatıyla kafileyi kendi adamlarına teslim ettiği, bu adamların da kendilerini dört gün alıkoyduktan sonra Hazro adlı yere gönderdiği bildirilir.

Burada Arafat gününde Mekke'ye yetişmek mecburiyetinde olan hacılar için para kadar değerli olan zaman mefhumunun koz olarak kullanıldığı, yavaşlatma eylemiyle hacılara baskı uygulandığı, hâkimlerin bu kazançlı işte ihaleyi yakınlarına devrettiği, aşikâre ve küstahça yapılan bu soygunların oldukça mahirane icra edildiği görülür.

Belgede daha sonra hacıların Hazro kalesine yakın Kelhut adlı kaleye ulaştığı, yerli halkın kaleden yola inerek önlerini kestiği, iki gün boyunca hacıların gitmesine izin verilmeyerek kendilerinden $b a \hat{c}$ adıyla bir miktar akçe aldıkları, daha sonra gitmelerine izin verdikleri anlatılır. Kervanın Hazro kalesinde yedi gün alıkonulduğu, hacılardan çok miktarda akçe toplandığ 1 , nefer basına altışar altın ödendiği, ellerinde ne var ne yoksa gasp edildiği yazılır. Hazro hâkiminin kendilerini kethüdası Kürt Muhammed Ağa'ya teslim ettiği, bu şahsın da bir miktar akçelerini gasp ettikten sonra kervana yol vererek Diyarbakır'a yönlendirdiği belirtilir.

Burada Diyarbakır'ın Acem hacıların sürekli vergi ödeme yeri olmasına rağmen daha önce kendilerinden alınanları göz önünde bulundurarak vergi vermekten israrla kaçındıkları görülmektedir. Nitekim bu çekincelerinde haklı oldukları çok geçmeden anlaşılmıştır. Hasankeyf bâcdârı olan Yezidi Kürtlerinin önlerini keserek kendilerini iki gün 
muhasara ettiği, içlerinden bir kaç neferi darp ederek yaraladığı, tüm mallarını yağmalayarak bundan sonra gitmelerine izin verdiği bildirilmiştir. Burada güzergâhtaki hâkimlerin devletlerarası bir krize mahal vermemek için hacıları bilinçli ve nitelikli bir şekilde maddi hasara uğrattığı, devlet karşıtı olan eşkıya ve bazı guruplarınsa firsatını bulduklarında hacıların canlarına kastettiği sonucu çıkmaktadır.

Belgenin devamında hacıların Batman suyu kenarına geldiklerinde Salman Bey denilen şahsın oğluyla beraber üç yüz nefer piyadeyle yollarına inerek kendilerinden zorla para aldığı anlatılır. Batman menziline kadar yaşanan tüm zulümlerin hacıları korumayla görevli Acem Ağası Mahmut'un vekili Ahmet tarafindan yapıldığı vurgulanır. Diyarbakır'a girişlerinde Eyyub Ağa adlı kişinin ortaya çıkıp "Ben Acem Ağasıyım, Diyarbakır gazisinden alınmış iznim var, hacılar için tayin edildim" diyerek değnek zoruyla her neferden on kuruş aldığı, hacıların "Bu kadar yoldan geldik, bir senede iki Acem Ăgası olmaz, iki avartz alınmaz, şu an ikiniz de aynı görev için burada nasıl hazır bulunuyorsunuz?" ş̧eklindeki itirazlarına rağmen Eyüp Ağa'nın buna kulak asmayarak zorla haraç aldığı zikredilir.

Diyarbakır'a ulaşabilen hacılardan bazısının vatanlarına döndüğü, bir miktarınınsa burada kalarak yola devam ettiği, Acem Ağası Eyüp'ün talimatına göre hareket edecek olan Acem kervanının beş gün daha bu şehirde tutulduğu, her birinden haraç alınarak salındığı kaydedilmiştir. Belgeye göre hacıların Siverek'e vardığında buranın zabiti Eyüp denilen şahsın bilgisi dâhilinde 3 gün alıkonulduğu, akçeleri ellerinden alınmadan gitmelerine izin verilmediği anlatılır. Devamında Milel-i Seray adlı mahalde, Ruha vergi memurunun iki yüz nefer adamıyla beraber hacıları muhasara edip bir miktar akçelerini aldığı, onları hapsedip gümrük adı altında para almadan gitmelerine izin vermediği, Birecik menziline geldiklerinde beş gün bekletildikleri, Murat suyundan geçerken bazılarından ikişer, bazılarından da sekizer altın gibi fahiş bir geçiş ücreti alındığı zikredilir.

Belgenin devamında hacıların "Allah Teâlầnın izzeti hakkı için; Kürdistan hâkimleri ve Acem Ağaları anlaşmalı olarak bu fakirleri her bir menzilde Freng esirleri gibi esir edip başka başka zulüm ve sitem etmiş, Ermeni ve Yahudi misli başımızı sayarak cebren vafir akçelerimizi ahz etmişler" sözleriyle yapılan bu haksızlıklara isyan ettiği, iki ülke arasındaki antlaşmalarda, "Bundan önce ihsan olunan emr-i âli de denilmişti ki; Acem Ağalarının avârız namı ile ve hükkam ve ummal haracı ve mal-i Miri ve Matracı Akçesi ve daha başka şaltak namı ile bir habbe almamalarına" dair hükmün yer aldığını hatırlattıkları görülür. Hacılar arasında ölenlerin mallarına göz dikilmemesi, malların varislerine teslim edilmesi gerektiği, fakat bunun mümkün olmadığı zira bu görevin sadece Acem Ağası'nın uhdesine bırakıldığı, onunda buna riayet etmediği ifade edilir. Hacılar Kürdistan hâkimleri ve Acem Ağa'sının kendilerini ortada bıraktığı, bu kısacık menzil yolunu çileyle dört ayda kat etmelerine sebep olduğu, Halep gümrüğü mesullerinin başlarından geçen olayları bildiği halde kendilerinden vergi istediğini, Halep menzilinden sonra Maarra ve Humus hâkimlerinin de aynı şekilde davrandığını zikreder.

Nihayet Halep'e ulaşan hacıların Arafat'a zamanında yetişmek için süratle acele ettikleri, Şam-1 Şerif'e ancak Şevval'in 25. günü vardıkları, fakat burada Şam kervanı Emir-i Hac Paşa Hazretlerinin Şevvalin 22. günü Şam'dan hareket ettiğini üzülerek öğrendikleri görülür. Hacılar bu hayati gecikmenin bölge hâkimleri, eşkıyalar ve Acem Ağası yüzünden 
olduğunu, bunların kendilerini bilerek yavaşlattıklarını, üçer beşer gün aralıkla en olmayacak yerlerde kendilerini durdurduklarını ifade ederler ${ }^{8}$. Acem hacıların geliş haberinin Şam Emir-i Haccı'na ulaştı̆̆ , Emir'in bir adamını göndererek onları kervana yetiştireceğine dair söz verdiği, kendilerine lütuf ve merhamet gösterdiği zikredilir. Fakat artık hacıların devam etmeye mecalleri olmadığı, Şam-1 Şerif'te kalmaktan başka çarelerinin bulunmadığını dile getirdikleri, kendileri için bir hal çaresi bulunmasını istedikleri görülür. Dertlerine derman arayan Acem hacılarının memleketlerine dönmek istedikleri, buna maddi güçlerinin olmadığı, masraflarının karşılanmadığı takdirde Şam'da ikamete mecbur kalacakları ifade edilir.

Burada değil hac kervanına ulaşmak, vatanlarına bile dönmeye takatleri olmayan hacıların çaresizliği açıkça görülmektedir. Şam'da kalmak istemeyen hacılar kayıpları karşılanarak ülkelerine dönme umudundadırlar. Öte yandan devletin bu hacıları Şam'da misafir ederek ertesi sene haccina kadar burada ikamet etmelerine izin vermesi gibi bir çareye yönelmesi şüphesiz farklı sorunlara yol açacaktır. Zira bunun örnekleri görülmüş, Şam, Halep, Diyarbakır gibi Osmanlı şehirlerinde kalan ve vatanlarına dönmeyen bir kısım Acem hacı ve tacirlerin Osmanlı tebaası kadınlarla evlenerek yeni bir soruna yol açtıkları tecrübe edilmiştir. (Serbestoğlu, 2012:214). Yapılacak tek şeyse hacıların kayıplarını karşılayarak ülkelerine ulaşmalarını sağlamak olarak gözükmektedir.

Belgenin sonunda Acem hacılarına ait çok sayıda mührün bulunduğu, mühür sahiplerinin tamamının haklarını yalnızca Kürdistan Acem Ağalarından talep ettikleri, yağmalanan malların tamamının her şahsa ayrı olmak üzere listelendiği görülmektedir. Bunca zulüm ve sitemin tarihin hiçbir döneminde meydana gelmediği, hacıların bu biçare hallerini hadlerini aşarak arz ve i'lam etmekten başka çarelerinin olmadığı bildirilir. Devletin bu şahıslar hakkında alacağı kararı bir an önce uygulamasını rica ettikleri, zulüm ve zor kullanan bu güçlülerin ancak bu yolla tenbih ve te'dip edileceğine inandıkları, bunun yapılması halinde devletin adaleti yerine getirerek zayıf ve miskinlerin hayır duasını alacağı ifade edilir. Bitlis'ten Diyarbakır'a Acem Ağası Mahmut Ağa'nın, Diyarbakır'dan Halep'e Eyüp Ağa'nın devlete hesap vermesi, görevden el çektirilmesi, bir daha asla Acem Ağası olarak tayin edilmemesi istenir. Kürdistan hâkimlerinden Erzurumlu Ahmet ve Ömer Ağa gibi şahısların eşkıyalarla birlikte haksız yere aldıkları tüm malları geri vermeleri, bu zulme sebep olanların ibreti âlem için yakalanıp cezalandırılmaları rica edilir.

Bu olayda görüldüğü üzere asıl suçlanan şahıs Osmanlı tebaasından seçilen Acem Ağa ${ }^{9}$ ve naipleridir. Fakat ne yazık ki gerek resmi belgelerde ve gerekse seyahatnamelerde Safevî hacıların zulüm ve haksızlıklarına sebep olan Acem Ağalarının Safevî döneminin

\footnotetext{
${ }^{8}$ Hadisenin yaşandığı h.1123 tarihinden yirmi yıl sonraki başka bir olayda Mekke'ye geç ulaşan Acem hacıları ibadetleri batıl olduğu için Mekke'de eylem yapmış, kusurun kendilerine ait olmadığını beyan ederek şikâyette bulunmuşlardır. Bu olay benzer hadiselerin devam ettiğine dair bir delildir. ( Caferiyan, 1371: C 14/39)

${ }^{9}$ Abbasiler döneminden itibaren Alevi nakipleri ya da İran hâkimlerinin Acem ağası görevini icra ederek hacıları Bağdat'tan Mekke’ye götürüp getirdiği, Selçuklular zamanında can ve mal güvenliğinin tehlikeye girdiği dönemlerde ise asker ve mevali komutanların hacılara emir olarak tayin edildiği bilinmektedir. Safevîler dönemine gelindiğinde ise Anadolu'dan geçenler için Acem Ağası tayin edildiği, Şam'a ulaşan bu hacıların emirinin ise Osmanlı devletinin tüm Müslüman hacılara tayin ettiği Emir-i Hacc olduğu görülmektedir. (Doğan, 2009:C.2/456).
} 
sonuna kadar aynı minval üzere tayin edildiği bilinmektedir. Şikâyetlerin Nadir Şâh döneminde ciddi boyutlara ulaştı̆̆ 1736'daki görüşmelerde de dile getirildiği, çözüm için hacılara İranlı bir şahsın emir tayin edilmesinde 1 srar edildiği bilinmektedir. Bu 1srarın sonunda ise talep Osmanlı devleti tarafindan nihayet kabul edilmiş, ve bundan böyle Acem Ağası İranlılardan seçilmiştir. (Koca Ragip Paşa, 2003: 91).

1711 tarihinde yaşanan bu elim hadisenin ayrıntıları Safevi mümessilleri tarafından yapılan şikâyeti anlatan bir Hattı Hümayun belgesinde verilmiş, kervanın Beyzade, ulema ve birçok önemli şahsiyetlerin aralarında bulunduğu yüz kişiden müteşekkil olduğu, dolayısıyla verilen bilgilerin dikkatle bildirildiği vurgulanmıştır. Özellikle Kemah Mütesellimi Burhan Hüseyin adlı şahsın bilgisi ve yardımı dâhilinde elli altmış kadar atlı eşkıyanın hücumuna uğrama olayı vurgulanmış, bu olayda yaşanan bir saatlik arbede sonunda üç kişinin öldürüldüğü, altı kişinin yaralandığı, iki yüz bin kuruştan fazla nakit paranın çalındığı, hacıların hayvan ve eşyalarının gasp edildiği zikredilmiş, buna göre de Kemah hâkiminin hesap vermesi gerektiği belirtilerek alınan tüm mal ve paranın iade edilmesine dair istidada bulunulmuştur. (BOA, HAT, Dosya no: 814, Gömlek no: 37270)

Elim hadisenin hemen akabindeyse Osmanlı Devleti'nin vakit kaybetmeden meseleye müdahale ettiği, hadiseyle ilgili gerekli yerlere hüküm sadır ettiği, hacılardan çeşitli adlarla alınan haraçların hiçbirinin asıl ve esasının olmadığ 1 vurgulanmıştır (BOA, C. \{ADL.626/1-1).Öncelikle menfur olayda taksiratı görülen Kemah Mütesellimi Dersaâdet'e çağrılmış, ardından Malatya ve Halep hâkimlerinin gözü önünde yapılan bu yağmalamaların, iki devlet arasındaki anlaşmalara aykırı hareketler olduğu bildirilmiştir. Hacılardan alınan vergilerin eskiden beri süregelen olağan vergiler olduğu yolunda savunma yapan ve böylece sorumluluktan kaçmak isteyen görevlilerin savunması devlet tarafindan göz ardı edilerek bunların hapis ve tevkifleri istenmiş, aldıkları tüm eşya ve paranın tahsil edilmesiyle ilgili mazbatalar taraflara aceleyle gönderilmiştir. Öte taraftan kaybolan malların tahsili ve kusursuzca mahalline teslimi için ilk önce emval tespit çalışması başlatılmış, kervan soymayı ve fenalığı alışkanlık haline getiren Kürt aşiretlerinden bazı şahıslar için Anadolu Ordu-yi Hümayun tarafından gerekli tedbir alınması istenmiş, eşkıyaların takibi başlatılmıştır.( BOA, A.\{MKT. HM 2/526) Benzer hadiselerin yaşanmaması için itina ve dikkat gösterilmesiyle ilgili olaya adı karışan tüm hâkim ve emirlere ihzar gönderilmiş, bu konuda başı çeken Harput Mutasarrıflığı'na gerekli önlemin alınması hakkında emirname yazılmış, kendisinden şüphe edilen mahalli memurların tamamının sorgulanması, çalınan malların geri alınması istenmiştir (BOA, A.\{MKT. UM 407/33)

Burada Acem hacıların kayılarıyla ilgili bu olayda devletin iyi niyeti ve hadiselere ivedilikle müdahale ettiği görülmekte, şikâyetleri göz önüne alarak olay hakkında süratli bir şekilde tahkikat başlattığı anlaşılmaktadır. Fakat bazı soruşturmaların bölge hâkimleri eliyle işlenmiş olmasından ötürü sonlandırılamadığı, çoğu zaman beyan edilenle çalınan mal arasında mantıki gerçekliğin olmadığı, hak sahiplerinin yolcu olmasından ötürü istenilen sürede taleplere cevap verilemediği, buna bağlı olarak suçluların derdest edilemeyerek hadisenin zaman aşımına uğradığı görülmektedir. Buradaki en önemli nokta şüphesiz Anadolu Ordu-yi Hümayun Müşir Hazretleri'ne yazılan son belgede devletin içinde bulunduğu sıkıntılar sebebiyle "bölgeye asker izamının mümkün olamamasından ötürü meseleyi askere muhtaç olmayacak bir şekilde çözüm getirilmesi" şeklinde bir tedbiri uygun görmesi, tabii olarak bu tedbirin çözümde yetersiz kalmasıdır. (BOA, A.\{MKT. NZD, 
121/87.) Neticede tüm bu kararll1ığa, alınmak istenen önlem ve ciddiyete rağmen ortaya çıkarılan malların ne yazık ki çalınanların sadece bir kısmı olduğu, sorumluların az bir kısmının cezalandırıldığı anlaşılmaktadır.

\section{Sonuç}

Özü itibariyle bir vahdet eylemi olan hac, savaş dönemlerinde bile edası aksatılamayacak bir ibadettir. Hac tarihine bakıldığında bu durumun defalarca göz ardı edildiği görülür. Hicaz’ı elinde bulunduran Osmanlı devleti dünya Müslümanları arasında Safevî hacılarına da ev sahipliği yapmış, Acem hacıların tamamı Osmanlı toprağından geçen resmî ve gayr-1 resmî güzergâhlardan hacca gidip gelmişlerdir. Devlet tarafindan bu hacılardan kendi huzurları için Şam'a ulaşarak buradan Mekke'ye gidecek resmî kervanlarla yolculuk yapmaları istenmiştir. Safevî hacılarını Şam'a ulaştıracak güzergâhlardan ikisi Anadolu'nun doğu vilayetlerinden geçmektedir. Erzurum-Urfa-Halep ya da Van-Urfa-Halep bağlantı yollarıyla Şam'a ulaşan bu güzergâhların oldukça sıkıntılı olduğu, Acem hacıların bu yollarda sık sık saldırıya uğradığı görülmüsstür. Bu saldırıların en büyük etkeni hiç şüphesiz hacıların Şii ve düşman olarak görülmesi ve mallarının helal olarak algılanmasıdır. $\mathrm{Bu}$ düşmanlık Acemlerin Şii olsa da hacı olmaları gibi dinî ve insanî yönünü unutturmuş, aksine karşı1lıklı tanınan, kesinlikle silahsız olan bu hak yolcularını dinî-siyasî rakip olarak algılamaya, halkın ve hâkimlerin hedefi haline getirmeye, iki ülke kararlarını çiğneyerek görmezden gelmeye itmiştir. Acem hacılar Anadolu'da Sünni, Alevi, Yezidi gibi dini; Türk, Kürt, Arap gibi farklı etnik yapıya sahip bölgelerden geçmek zorunda olmuşlardır. Merkezden uzak, tam bir hâkimiyetin söz konusu olmadığı bu yerlerden geçerken korunacaklarına dair güvence verilmelerine rağmen saldırılarda can ve mallarından olmuş, buna rağmen Acemlerin hac ve Atabât ziyaretleri hiçbir zaman son bulmamıştır.

Meseleye Osmanlı devleti nazarından bakıldığında önceleri haklı olarak şüpheyle bakılan Acem hacılarına ilerleyen dönemlerde diğer Müslüman tebaa hacıları gibi davranıldığı görülmektedir. Canları ve mallarının korunmaya çalışıldığı, Haremeyn ve Haremeyn'e giden yolların hâkimi/hadimi olan Sultan'ın sıfatına gölge düşürücü olaylara derhal müdahale edildiği, savaş dönemlerinde yolculuklarının kati surette engellenmeye çalışıldığı, bu tedbirlere rağmen sorunun bitmediği, yaşanan bazı olaylardaki soruşturmalarınsa zaaf ve ihmalle sonlandırılamadığı görülmektedir. Taksiri doğrudan devlete mal edilemeyecek bu tür saldırıların aslında Malatya-Akçadağ, Harput-Karadağ, Hasankeyf-Yezidi Kürt aşiretleri gibi hacıların amansız düşmanı olan eşkıya taifesinin eseri olduğu anlaşılmaktadır. Bununla beraber hacıların can ve mallarından asıl sorumlu olan tarafin Hadim'ul Harameyn olduğu, uluslararası meydanda cevap merciinin devlet olduğu görülmektedir.

Safevî Devleti nazarından olaya bakıldığında ise devletin dinî ve siyasî rakibi olarak gördüğü komşu ülke topraklarından geçerek hacca gidecek tebaasını önceleri engellemeye çalıştığı, bu hacılara yol emri yani pasaport vermediği, fakat zamanla bu kabul edilmeyen siyaseti bir kenara bıraktığı anlaşılır. Devletin başlarda tebaası olan hacıların hakkını savunmada hâkimiyetini sarsan ve kendini küçük düşüren pasif siyaseti aşamalı bir şekilde bıraktığı, Safevî hacıların da diğer yabancı memleket Müslümanları gibi dinen ve örfen hacca gitmeye hakları olduğunu vurgulayan bir siyaset izlediği, barış dönemlerinde ibadetlerini eda etmek üzere güvenli yolculuklar için imkân tanınması yolunda harekete geçtiği, şikâyetleri maslahatgüzarları aracılığı ile hükümete ilettiği görülür. Safevî 
Devleti’nin resmi belgelerinde geçtiği üzere davaları takip ettirerek sonuca ulaştırmak için mükerrer hatırlatmalarla çaba gösterdiği, imzalanan antlaşmalarda hacılar meselesini her daim gündeme getirerek caydırıcı kararlar aldırmaya çalıştığı, bu yolla hacıların haklarını korumaya önem verdiği görülür. Fakat devletin başlarda sorunu görmezden geldiği, genel anlamda ise içinde bulunduğu siyasî zaaf ve iktisadî buhran sebebi ile özellikle yıkılış döneminde tebaasını Osmanlı topraklarında gereği gibi koruyamadığı anlaşılır.

Konu Acem hacıları açısından değerlendirildiğinde ise Anadolu'daki bu saldırıların tarih boyunca yaşadıkları sıkıntıların bir benzeri ve sadece biri olduğu, bu saldırıların Şam ve Irak bölgesindeki Anize; Necd ve Ahsa bölgesindeki Haface kabile saldırıları kadar caydırıcı olsa da farz bir emri edadan geri durmadıkları, can ve mal güvenliklerini hiçe sayarak hacca gittikleri görülür. Yollarda kendilerini yalnız hisseden Acem hacılarının, sıkıntılarına son vermekten aciz olan devletlerinden yardım istemek yerine, şikâyetlerini çoğu kez Osmanlı devletine bildirerek çözüm aradıkları anlaşılır. Dinen bir mezheben farklı iki İslam ülkesi arasında kalan Acem hacıların bu sorunlarını sadece dini bakış açısıyla değerlendirmek elbette doğru olmayacaktır. Meselenin salt Osmanlı-Safevi kaynaklarıyla anlaşılamayacağı da açıktır. Bu çalışmada yapılan değerlendirmelere yeni ve farklı yorum ve kaynakların boyut kazandıracağı ise kesindir.

\section{Kaynakça}

Amuli, C.M. (1368). Zendegan-i Siyay-i Imam Riza, Tehran: Be Münasebet-i Kongrey-i Cihan-i Hazreti İmam Riza Aleyhisselam.

Amuli, M.(1380). Vesail-i Şie ila Tahsil-i Mesail-i Şie, Kum, Mektebetül İslamiyye.

Atalar, M. (1992). Surre-yi Humayun, Ankara: Diyanet yayınları.

Beşe, A. ve Tozlu, S. (2011). 'İngiliz Kayıtlarında Aleviler Ve Bektaşiler', Türk Kültürü ve Hacı Bektaşi Veli Araştırma Dergisi, 59: 195-220

Beygleri, S. H. H. (1340). Ahkâm-i Hac ve Esrar-i An, Tahran

Burkay, K. (1992). Geçmişten Bugüne Kürtler ve Kürdistan Coğrafya-Tarih Edebiyat, İstanbul: Deng Yayınları.

Caferiyan, R. (1371). ''Huccac-i İraniyan der Dovrey-i Safevî', Mecelle-i Mikat, 14: 87-109

Caferiyan, R. (1373). 'Dastan-i Koşte Şodeni Şehid Sani der Sal-i 965 hicri der Mekke”. Miras-i İslam-i Iran, Defter-i Evvel: 392

Caferiyan, R. (1383). Munasbat-i İsfahan ve Hicaz Der Ruzigar-i Safevî, Kaveşhay-i Taze der Bab-ı Ruzigar-i Safevî, Kum: Merkez-i Mutalaat ve Tahkikat-i Edyan ve Mezahip

Cantay, G, (2001). 'Güney-Doğu Anadolu Ticaret Yolları ve Menzil Kuruluşları',, Ortadoğu'da Osmanlı dönemi kültür izleri uluslararası bilgi şöleni bildirileri.1(7):415430

Cutillas, J. (2016). 'Şâh I. Abbas'ın Bir Akdeniz Politikası Var Mıydı?', (Çev. Külbilge, İ) Cihannüma Tarih ve Coğrafya Araştırmaları Dergisi. 2(2): 189-210.

D.Turay, E. (2018). 'İranlıların Kudüs-i Şerif Ziyaretleri', Osmanlı Mirası Araştırmaları Dergisi, 5(12):125-145.

Dalkesen, N. (2005). '’15 ve 16. Yüzyıllarda Safevî Propagandalarının Anadolunun dini ve kültürel hayatındaki etkileri, Alevi Kızılbaş Kimliğinin Oluşumu’, Kırkbudak, 1 (1): 2049.

Doğan, E. (1387). 'Huccac-1 Türkistan I-II', Mecelle-i Mikat, 54.123-152: 55: 146-189

Doğan, E. (1389). Tarih-i Hac Gozariy-i İraniyan, Tahran: Neşr-i Meşar.

Doğan, E. (1397). Huccac-i İrani der Dovleti Osmanî (Garn-i 13 ve 14 Gameri).Tahran: Pejuheşgah-i Tarih-i İslam. 46-78. 
Doğan, E. (2008). ''Dersaadet'ten Harameyn'e Surre-i Hümayun', İçinde: Kacar Dönemi Sefernâmelerinde Osmanlı Hac Kervanlart, (Ed. Cağlar. Y), İstanbul: Yitik Hazine Yayınlar1.

Doğan, E. (2009). 'Safevîler ve Şâh İsmail'. Safevîler Döneminde Osmanlı Ülkesine Seyahat, (Ed. Taşkın, A), İstanbul: Önsöz Yayınları.

Doğan, E. (2010). 'Menazilnameha Der Edebiyati Hacc-i Osmanî', Cong, Fehrestnegaran-i Nushay-i Hatti, 1.332-356.

Doğan, E. (2011). 'Büyük Selçuklu Devleti ve Horasan Hac Kervanları', I. Uluslararası Selçuklu Sempozyum Bildirileri, 2: 456-489

Doğan, E. (2012). 'Ordubadlı Safevî Şâiresi ve Hac Seyahatnamesi”. Müslman Şarqinda İlk Dünyevi Qız Mektebinin Yaradılmasının 110 Illiyine Hasr Olunmuş Beynelxalq Elmi Simpozium Maruzeleri, Bakü, 33-43

Doğan, E.(1375). 'Rahhay-1 Hac der Dovre-i Safevî yye', Mecelle-i Mikat, 57: 34-65

Ekinci, M.( 2010). 'Safevîyye Tarikatı ve Türkmenler Üzerindeki Rolu'. Anadolu'da Alevilerin Dünü ve Bugünü. (Ed. Bulun, H.İ), Sakarya: Sakarya Üniversitesi Yayınları.

Emhezun, M. (1985). el-Medinetü'l-Münevvere fi rıhle el Ayyaşi, Kuveyt: Daru'l-Erkam.

Faroqhi, S. (1995). Hacılar ve Sultanlar (1517-1638), (Çev. Güven, G.Ç) İstanbul: TTVY

Felsefi, N.(1347). Zendeganiy-i Şâh Abbas Evvel, Cild-i Evvel, Mugaddemat-i Saltanat-i ez Vilayet ta Padişâhi, Tahran: İntişarat-i Danişgah-i Tehran.

Güler, M. (2016). ' 'XIX. Asırdan Günümüze Kırgizistan'da Hac Olgusu ve Osmanlı Devleti'nin Bölge Hacılarına Yaklaşımı', Afyon Kocatepe Üniversitesi Sosyal Bilimler Dergisi, 18(1): 1-16

Handmir, C.Ş. (1380). Habibussiyer fi Ahbari Efradil Beşer, (Ed. Keyani, C), Tahran.

Harezmî, Ş.H. (1390). ' 'Cadde-i Aşıkin', (Ed. Caferiyan.R), Mecelle-i Baharistan.1: 11-77

Hatunabadi, (1369). Vekay-i Senin. Tahran.

Hilli, M. (1353). Şerayi u' İ İlam, (Çev. Yezdi. A), c.1, Tahran: İntişarat-i Danişgah-i Tehran Işıksel, G. (2012). '16. Yüzyılın İkinci Yarısında Osmanlı-Safevî Sınırında Eşkıyalar, Bir Çözümleme Denemesi', Kebikeç. 33: 37-48

I'tizadusslatane, A.G.M. (1365). Tarih-i Vegayi' ve Sevanih-i Afganistan. (Ed. Muhaddis, M.H) Tahran: Emir Kebir.

İlm'ul Huda, S.M. (1379). Cevamiul Fıkhiyye. Kitab 'ul Hac, Tahran: İntişarat-1 Cihan.

İrfanmeneş, C. (1374). Coğrafyay-i Tarih-i Hicret-i İmam Rıza ez Medine ta Merv . Meşhet: Astan-i Guds-i Rezevi.

K.Çınar, G. (2015). ''Özbek Hanlıkları Bağlamında Astrahan Seferi ve Kuzey Hac Güzergâhı', Yeni Türkiye. 73: 71-85.

Kaşani, M.F. (1388). Cong-i Molla Sadra, Tahran: İntişarat-i İttilaat.

Kılıç, O. (1999). ' 'Yurtluk-Ocaklık ve Hükümet Sancakları Üzerine Bazı Tespitler', OTAM, 10: 119-137.

Koca Ragıp Paşa, (2003). Tahkik ve Tevfik, İstanbul: Kitabevi Yayınları

Köse, B.A. (2009). Ortaçağ Seyahatnamelerinde Trabzon-Erzurum Güzergâhı, Erzincan Ve Kars (Coğrafi, Siyasi, Ekonomik Ve Kültürel Açıdan İncelenmesi), Ankara Üniversitesi Sosyal Bilimler Enstitüsü Yüksek Lisans Tezi, Ankara.

Küpeli, Ö .(2014). Osmanll-Safevi Münasebetleri, İstanbul: Yeditepe Yayınevi.

Lapidus, I.M. (2002). İslam Toplumları Tarihi I, (Çev. Aktay,Y), İstanbul: İletişim Yayınları.

Meclisi, M.T. (1379). Hatırat-ı Sefer-i Safeviyye der arse-i din ve Ferheng ve Siyaset. (Ed. Caferiyan, R) c.2, Kum: İntişarat Delil Ma 
Mehmed Paşa, B.D. (1977). Zübde-i Vekayiat: 1656-1689 c. (2) (Ed: Özcan, A), İstanbul: Tercüman Gazetesi

Melikoff, İ. (1998). Hacı Bektaş, Efsaneden Gerçeğe, İstanbul: Cumhuriyet Kitapları

Munşi, İ.B. (1350). Âlem Aray-i Abbasi, Tahran: c.1 Emir-i Kebir

Natanzi, M. H. (1373). Negavet'ul Asar fi Zikr-i Akhyar der Tarih-i Safevî yye, (Ed: İşragi, İ) Çap-i Dovvom, Tahran: İntişarat-i İlmi ve Ferhengi,

Nişancızade, M. (1841). Mirat-1 Kâinat, c.1,Kahire: Bulak Matbaası.

Orat, A.J. (2014). 'Yabanc1 Güçler Gölgesinde Osmanlı Devleti'ne Yönelik Şia Hareketleri', Avrasya Uluslararasi Araştırmalar Dergisi, 3 (5): 62-73.

Osmanlı Arşivi Daire Başkanlığı Osmanlı Belgelerinde Surre Alayları, (2010). Ankara: BOA, Genel Müdürlüğ̈̈. Yayın No: 116

Sefernâmey-i Manzum-i Hac. (1374). (Ed. Caferiyan, R), Tahran: Meşar.

Senendeci, Mirza Ş. (1375). Tuhfe-i Nasiri, Tahran: Emir Kebir.

Serheng, H.H.B.(1340). Ahkâm-i Hac ve Esrar-i An, Tahran.

Sertoğlu, İ. (2012). 'Öteki Perspektifyle Osmanlı Kadınının İranlılarla Evlenme Yasağı'. Uluslararası Sosyal Araştırmalar Dergisi, The Journal of International Social Research, 5(20): 213-220

Sibai, A. (1999). Tarih-i Mekke, c.l. Mekke: Mektebe'tul Arabiyyet es Suudiyye

Tekindağ, Ş. (1967). "'Yeni Kaynak ve Vesîkaların Işı̆ğı Altında Yavuz Sultan Selim'in İran Seferi". İstanbul Üniversitesi Edebiyat Fakültesi Tarih Dergisi, 17(22): 49-78

Tezkire-i Safevîyye, (1369). (Ed.Parisi, İ.B), Tahran: Neşri İlm

Vahidi, M. (1386). Sefer, Ahkâm ve Adab, Kum: Merkez-i Naşir-i Senabi.

Vambery, A, (1380). Tarih-i Buhara, Tahran: Suruş.

Xemgin, E. (1997). Kürdistan Tarihi, İstanbul: Doz Basım Yayınları.

\section{Arşiv Kaynakları}

Başbakanlık Osmanlı Arşivi (BOA), 6 Numaralı Mühimme Defteri(MD), Ankara, 1995

BOA, 7 Numaralı Mühimme Defteri, Ankara 1997.

BOA, 7 Numaralı Mühimme Defteri, Ankara, 1999

BOA, Hat. Hüm., 814, 37270

BOA, Cev.Har., 1128

BOA, Cev.Adl., 626/1-1

BOA, Sad.Mek. Kal. Bel. Har., 2/526

BOA, Sad. Def. Um.,407/33

BOA, Sad. Def. Nez. Dev.,121/87 